\title{
TMI diszfunkcióval rendelkező páciens komplett ellátása
} Esetismertetés

\author{
DR. SÁPI BÉLA, DR. NEMES JÚLIA, DR. TÓTH ZSUZSANNA
}

\begin{abstract}
A nem megfelelő temporomandibuláris ízületi pozíció következménye a rágóizomzat hibás müködése is lehet, amely gyakran más területen is jelentkező, igen különböző tünetekért felelős. A korszerű fogorvosi felfogás szerint a komplett protetikai rehabilitáció során a rágószervek - mint a szervezet egészébe illeszkedő anatómiai és élettani egységek optimális pozíciójának elérésére törekszünk. Ezért fontos, hogy kiterjedtebb fogpótlás készítése során felhasználjuk gnatológiai alapismereteinket, hiszen így megelőzhetünk/helyreállíthatunk állkapocs-ízületi problémákat is. A bemutatott esetben egy 72 éves hölgy páciens krónikus fej- és nyakfájását sikerült megfelelő protetikai ellátással panasz és tünetmentessé tenni.
\end{abstract}

Kulcsszó: esetismertetés, temporomandibuláris diszfunkció, egyéni értékű artikulátor, individualizált fogpótlás készítése

\section{Bevezetés}

A rágószervrendszer a muszkuloszkeletális rendszer része, állcsontokból, rágóízületekből, szalagokból, izmokból és inakból áll. Az angolszász szakirodalom a temporomandibuláris elváltozásokat „temporomandibular disorders"-nek (TMD) nevezi. A TMD tehát egy gyűjtő-diagnózis, amelyhez több különböző elváltozás sorolható. Lényegében ide tartozik minden kórkép a temporomandibuláris rendszer malignus elváltozásai, valamint a tájék ér- és idegellátását érintő betegségein kívül. A temporomandibuláris diszfunkció igen gyakori muszkuloszkeletális elváltozás, melyben az emberek 40-75\%-a érintett, és minden harmadik embernél tüneteket is okoz. Igaz ugyan, hogy ezek a betegek csupán 5-15\%-ban igényelnek valóban kezelést, 3-7\%-uk azonban feltétlenül kezelésre szorul. A páciensek jelentős része az elváltozást csak az alapfunkciók - szájnyitás, beszéd, rágás, ásítás - sérülésekor vagy teljes elvesztésükkor észleli [1, 2, 3, 4].

\section{Etiológia}

A betegség etiológiáját tekintve a kóroki tényezők sokasága merül fel, azoknak a betegség kialakulásában betöltött jelentősége azonban erősen vitatott. Általánosan elfogadott konkrét etiológiai faktor nincs. A leggyakrabban macro-microtraumák, anatómiai faktorok (pl. az eminentia articularis meredeksége, szkeletális és dentális okklúziós eltérések), általános és helyi patofizioló- giai tényezők (reumatológiai, neurológiai, szájsebészeti és egyéb fogászati kórképek), pszichoszociális faktorok (pl. depresszió, szorongás, stressz) állhatnak az elváltozások hátterében. Az ízületi elváltozások napjainkban leginkább használt diagnosztikai módszere az úgynevezett RDC/TMD (Research Diagnostic Criteria/TMD). Ez a módszer a temporomandibuláris ízületi diszfunkciót egy kéttengelyes rendszernek állítja be, melyben az első tengelyen a fizikális faktorok, míg a második tengelyen a pszichoszociális faktorok reprezentálódnak. Az elöbbi alapján megkülönböztetünk miofasciális fájdalmat, discus dislocatiókat és vegyes ízületi eredetü kórképet [2, 3, 6, 7, 8, 9, 10, 11, 12].

\section{Kezelés}

A TMD kezelése alapvetően két részre osztható, elsősorban a reverzibilis, konzervatív terápia (fázis I.) választandó, majd az irreverzibilis terápia (fázis II.). A konzervatív terápiához tartozik a páciens gyógyszeres kezelése, mozgásterápia (aktív, passzív), elektroterápia (TENS), mechanoterápia (ultrahang), fototerápia (lézer), termoterápia és Kinesio Tape használata. Ha ezek nem hatékonyak, elkezdhető az irreverzibilis terápia, amely lehet a fogak becsiszolása, fogszabályzó-kezelés, fogpótlás készítése, szájsebészeti beavatkozás. Természetesen a fázis II. is lehet az először választandó terápia, nagyfokú rendellenességeknél vagy ha a páciensünk teljes rehabilitációjához mindenképpen fogpótlások készítésére van szükség [2, 3, 6, 11, 12]. 


\section{Esetismertetés}

A 72 éves hölgy páciens azért érkezett a SE Konzerváló Fogászati Klinikára, mert sem funkcionálisan, sem esztétikailag nem volt elégedett 25 éve készült hídpótlásaival. Emellett pár hónapja fennálló állkapocs ízületi kattogásról és krónikus fej- és nyakfájásról panaszkodott (1. kép). Általános anamnézisében a kezelést befolyásoló tényező nem szerepelt, rendszeresen gyógyszert nem szedett. A szájhigiénia a számos plakkretenciós tényező miatt nem volt megfelelö. A hölgy élharapással és jobb oldali keresztharapással rendelke-

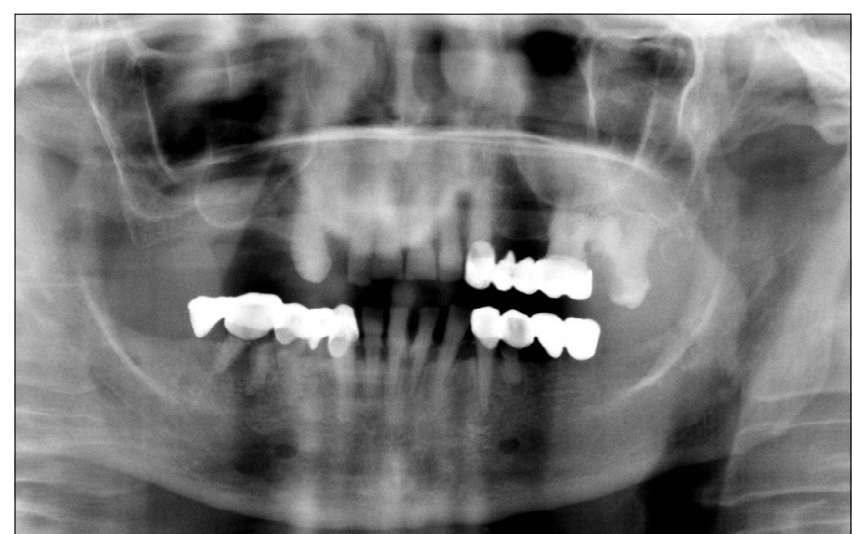

1. kép: kiindulási panoráma felvétel

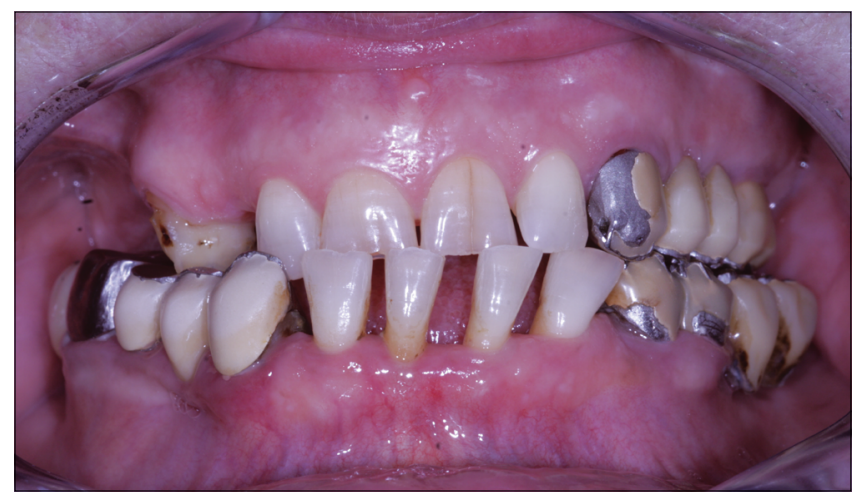

2. kép: kiindulási interkuszpidációs helyzet

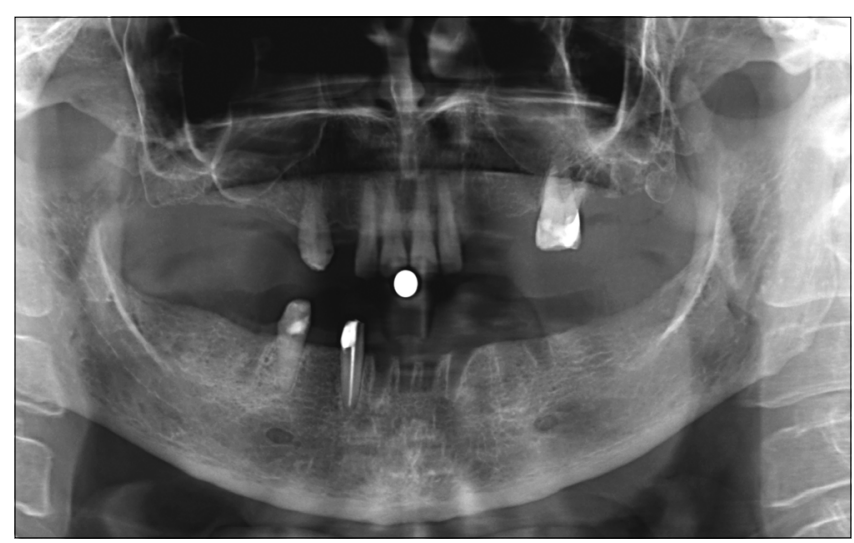

3. kép: szanálás utáni panoráma felvétel zett, mely elmondása szerint az utóbbi pár hónapban alakult ki. Az intraorális vizsgálat az alsó és a felső állcsonton is vesztibulárisan műanyag leplezésű könnyen mozgatható híd-pótlásokat regisztrált. A hidak mozgathatósága a pillérfogak magas fokú mobilitásának és a kiterjedt szuvasodásoknak volt köszönhető (2. kép). A temporomandibuláris ízület vizsgálata során az izmok palpatióra való érzékenyeksége, az auscultatiós vizsgálat során enyhe crepitatió volt észlelhető mindkét ízületben. Szájnyitási korlátozottság, deviáció/deflexió jelensége nem volt megfigyelhető.

Az előzetes kezelési tervben a páciens professzionális szájhigiéniás kezelése, instruálása, motiválása, a régi pótlások eltávolítása és a teljes fogazat szanálása szerepelt. A 23, 27, 33, 34, 46 fogak a nagyfokú destrukció, a 31, 32, 41, 42 fogak pedig a III. fokú mozgathatóság miatt eltávolításra kerültek. A 43 fogra annak gyökérkezelése után kompozit felépítmény, a 13, 26 és 35 fogakba pedig kompozit tömés készült. A kiindulási helyzet a Fábián- és Fejérdy-féle osztályozás alapján az alsó állcsonton 2B-ről 2A/1-re változott, a felső állcsonton változatlanul maradt a kiindulási 2B osztály. A végleges protetikai rehabilitációt a megtartható fogak határozták meg (3. kép): a felső állcsontra finommechanikai (Preci-Vertix) és öntött kapocs elhorgonyzású kombinált fogpótlás (4. kép), az alsó állcsontra pedig cilindrokónuszos-teleszkóp elhorgonyzású fogpótlás készült (5. kép).

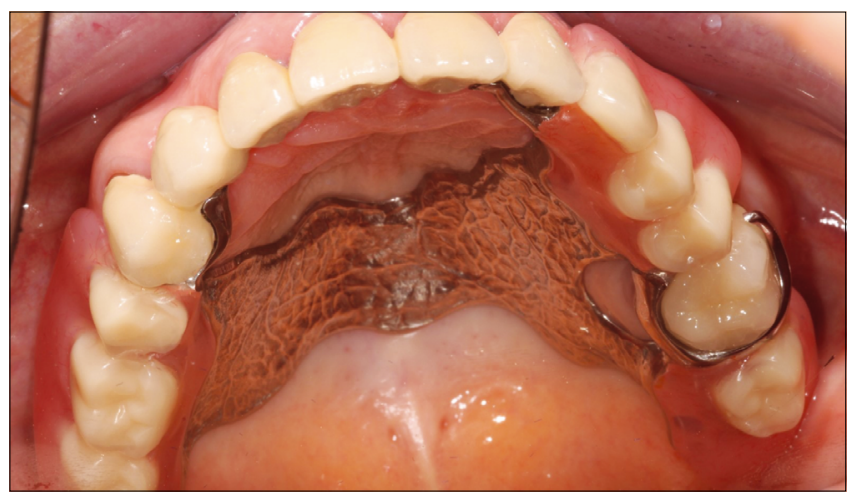

4. kép: felső fogpótlás átadást követően

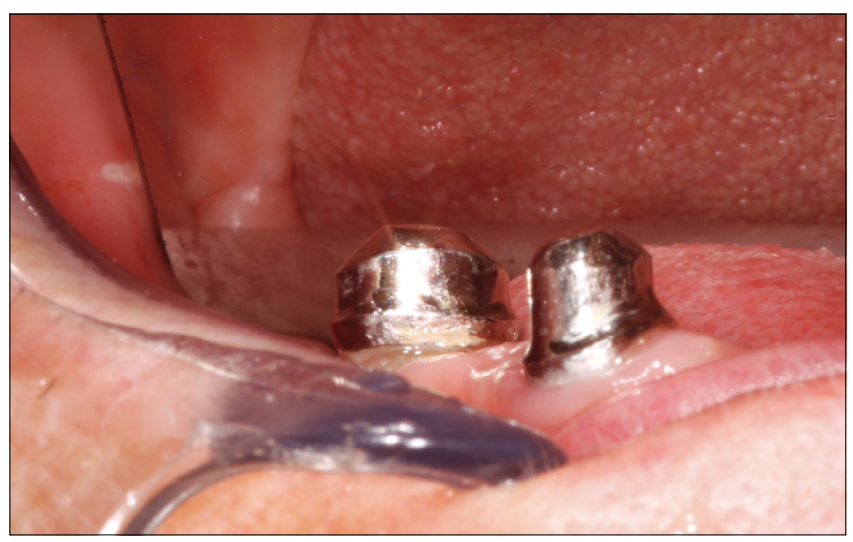

5. kép: primer teleszkópok beragasztást követően 
Az egyéni értékeknek megfelelő fogpótlások készítése érdekében a kezelés során Protar 5 típusú egyéni értékű artikulátor került felhasználálásra. A hozzá konstruált arcívvel lehetett meghatározni a maxilla pontos térbeli helyzetét a frankfurti horizontálishoz viszonyítva. A maxilla-mandibula egymáshoz való elhelyezkedésének detektálása intraorális rajzolóeszközzel történt. A centrális occlusio verticalis dimenzióját (fizikai harapási magasság) egy, a felső harapási sablonban elhelyezett rajzolószög segítségével lehetett beállítani úgy, hogy a hölgy fiziológiai harapási magasságából (nyugalmi helyzetben mért távolság a felső és alsó állcsont között) levonásra került az interocclusiós térköz értéke (2-3 mm). A megfelelő mozgások (propulsio és mindkét oldali lateropulsio) elvégzése után már a horizontális komponens is rendelkezésre állt a megkapott nyílhegyrajzolatnak köszönhetően (6. kép). Az állkapocs mozgásainak egyéni szögeit 3-3 harapási sablonnal lehetett rögzíteni (7. kép).

A szagittális fejecspálya szögértékének meghatározásához propulsióban, a Bennett-szögek definiálásához pedig lateropulsiókban kellett egymáshoz rögzíteni az

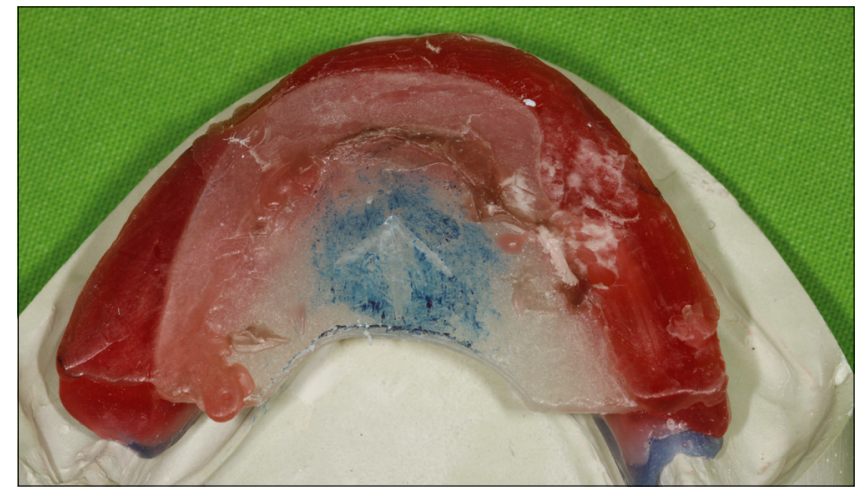

6. kép: az intraorális rajzolóeszköz és a nyílhegyrajzolat

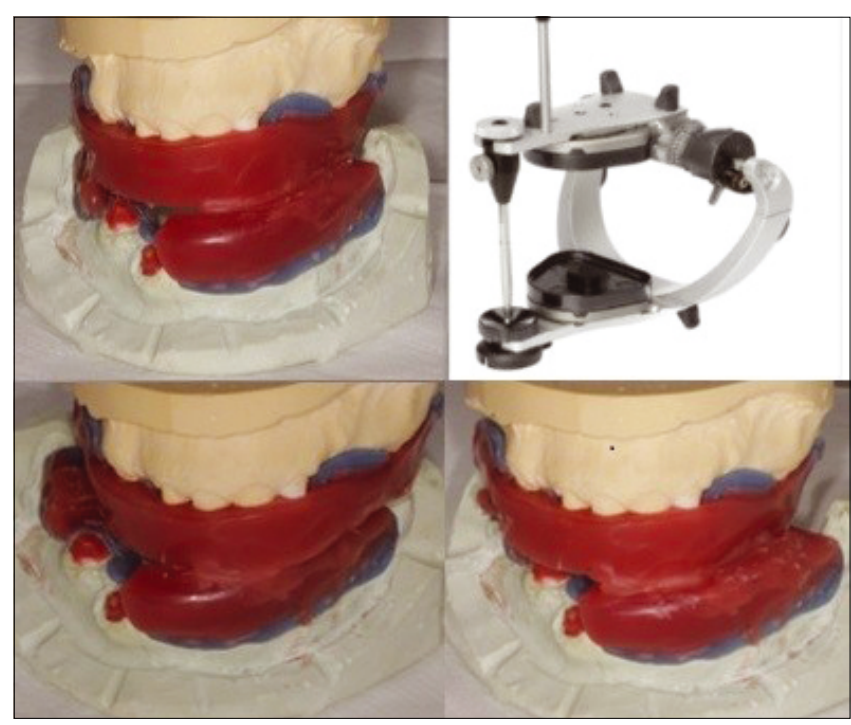

7. kép: Protar 5 típusú egyéni értékủ artikulátor és a megfelelő pozícióban (propulsio, leteropulsio) rögzített harapási sablonok

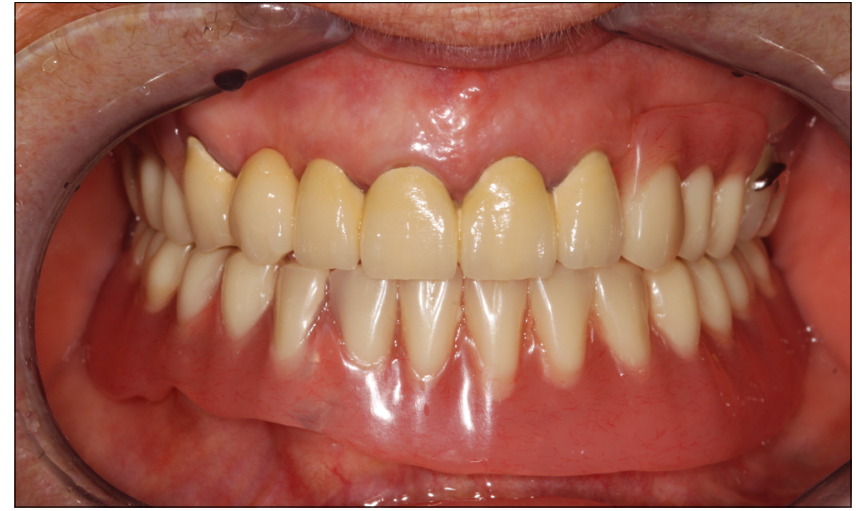

8. kép: Az elkészült fogpótlások átadása

alsó és felső harapási sablonokat. Ezek után a fogtechnikai laboratórium közreműködésével már elkészülhettek a megfelelő, individualizált fogpótlások (8. kép).

\section{Eredmény}

Páciensünknél a nem megfelelő occlusiós viszonyok miatt előrehelyezett kényszerpozíció, és ezért az ízület és az izmok túlterhelődése alakult ki. Primer occlusiós kiváltó ok volt tehát jelen, amely a beteg panaszainak eszkalálódását okozta.

Az új fogpótlással mind funkcionálisan, mind esztétikailag helyreállításra került a páciens fogazata. Az elkészült fogpótlás átadása után rövid időn belül csökkentek a hölgy állkapocs-ízületi panaszai, krónikus fej- és nyakfájdalmai enyhültek, 3 hónap elteltével teljesen meg is szüntek. A páciens a kezelés befejezése óta eltelt 2 évben panasz- és tünetmentes, az elkészült pótlással maximálisan elégedett (9. kép).

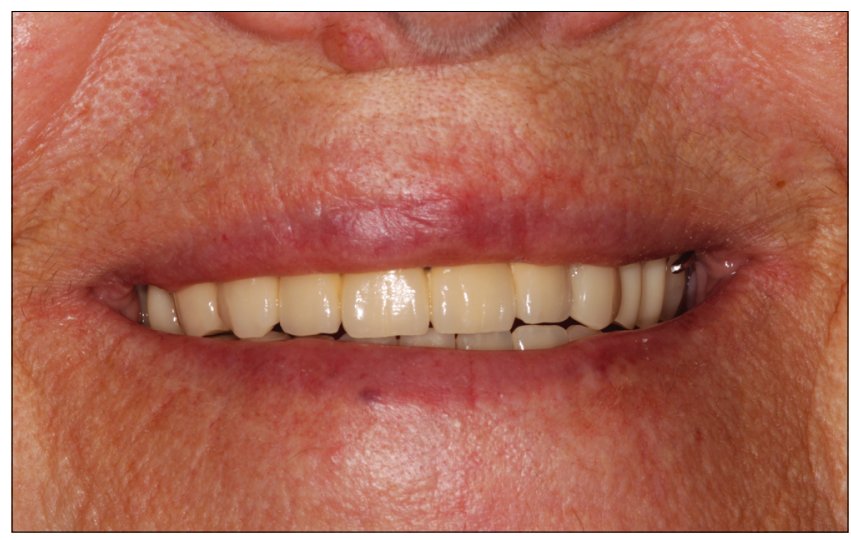

9. kép: Az elégedett páciens mosolya

\section{Irodalom}

1. Angyal J: Temporomandibuláris ízület betegségei. Fogorvosi Szemle. 2002; 95 (5): 181-188.

2. Balogh I, Jász M, Schmidt P, Hermann P (szerk.): A temporoman- 
dibularis ízület megbetegedéseinek diagnosztikai és terápiás lehetőségei. Fizioterápia. 2. 2012; 21. (1): 3-9.

3. MolnÁR A: A temporomandibuláris ízület rendellenességei és azok rehabilitációi. http://hdl.handle.net/2437/194700 2014.

4. KIss G, PÁcz M, KIss P (szerk.): Rágószervi funkciózavarok diagnosztikája. Craniomandibularis rendszer dysfunctiója (CMD). Fogorvosi Szemle. 2011; 104. (3): 93-102.

5. LERESCHE L: Epidemiology of temporomandibular disorders: implications for the investigation of etiologic factors. Crit Rev Oral Biol Med. 1997; 8: 291-305.

6. Schmidt P, Jász M, Angyal J, Hermann P: A vizsgálat menete és terápiás lehetőségek a temporomandibuláris ízület megbetegedéseinél (I. rész). Magyar Fogorvos. 2009; 4: 169-173.

7. LASKIN GC, HYLANDER W: TMD's: an evidence-based approach to diagnosis and treatment. Quintessence, Chicago, 2006.

8. RUGH JD, Davis SE: Temporomandibular disorders: Psychological and behavioral aspects. In: Sarnat BG, Laskin DM (eds). The
Temporomandibular Joint: A Biologic Basis for Clinical Practice, ed 4., Saunders, Philadelphia, 1992; 329-345.

9. Truelove El, Sommers Ee, LeResche L, Dworkin SF, Von Korff M: Clinical diagnostic criteria for TMD: new classification permits multiple diagnoses. JADA. 1992; 123 (4): 47-54.

10. Suvinen TI, Reade PC, Kemppainen P, Könönen M and F Dworkin S: Review of aetiological concepts of temporomandibular pain disorders: towards a biopsychosocial model for integration of physical disorder factors with psychological and psychosocial illness impact factors. Eur J Pain. 2005; 9 (6): 613-633.

11. Talley RL, Murphy GJ, Smith SD, Baylin MA, Haden JL: Standards for the history, examination, diagnosis, and treatment of temporomandibular disorders (TMD): a position paper. J Craniomandibular Pract. 1990; 8: 60-77.

12. Fatin Hasanain, et.al: Adapting the diagnostic definitions of the $\mathrm{RDC} / \mathrm{TMD}$ to routine clinical practice: A feasibility study. $J$ Dent. 2009; 37: 955-962.

\section{SÁPI B, Nemes J, TÓth Zs}

\section{The comprehensive therapy of a patient with TMJ dysfunction Case presentation}

An inadequate temporomandibular-joint position might cause chewing muscles malfunction, which can be responsible for various symptoms in other areas of the body as well. According to the requirement of modern dentistry during the complete prosthetic rehabilitation we strive for an optimal position of the masticatory apparatus. Therefore gnathological basics are important to use in preparing extensive prosthetics. In this case report a 72-year-old female patient with chronic headache and pain in her neck was treated successfully with prosthetic care.

Keywords: case report, temporomandibular dysfunction, adjustable articulator, individualized prosthetic care 